\begin{tabular}{|c|c|c|}
\hline & PORT SAID UNIVERSITY RESEARCH JOURNAL \\
\hline & Faculty of Engineering- Port Said University \\
Volume (20) No.2 & September 2016 pp: 96 - 109
\end{tabular}

\title{
Stability Aspects of Bulk Carriers
}

\author{
Nourhan Ibrahim Ghoneim ${ }^{1}$,El-Sayed Hegazy ${ }^{2}$, Mohamed A. Kotb ${ }^{3}$ and Adel A. Tawfik ${ }^{4}$
}

\section{ABSTRACT}

Bulk carriers are one of the three dominating merchant ship types together with grain and container vessels. Today, bulk carriers comprise about one third of the world fleet in tonnage terms. The demand for raw materials like coal, iron, copper, ...etc., has increased considerably since the turn of the millennium. Moreover, the bulk carrier has specific nature due to the loaded bulk cargo's parameters which may slosh, liquefy, shift...etc.

The intact stability of bulk carriers is investigated, with respect to the latest regulations developed by IMO. The effect of loading conditions and types of cargoes on ship stability and cargo earning capacity are studied. It is found that in some cases of loading conditions with certain types of cargo we have to use ballast water to satisfy the new grain regulations. This will lead to a reduction in the cargo earning capacity of the ship. The study under consideration is very important from the economic point of view of the vessel's operation. Ship's owners and charters must know which type of bulk cargoes is more profitable in case they have a choice to carry different types of bulk cargoes.

A computer program is developed to carry out the stability calculations. Firstly we should get the vessel's lines plans drawings, then using these drawings to prepare the vessel's tables of offsets. Using these tables of offsets and Model Maker Program, full model of ship's sections at different stations and the general arrangement can be obtained.

Take this model in the Auto Hydro program to do the different loading conditions calculations. A programing code is written and to be run to check the compliance with the intact stability criteria.

Keywords- Bulk carriers- stability- Bulk cargo

Abbreviations and notations:

\begin{tabular}{|c|c|}
\hline DWT & : Deadweight in (ton) \\
\hline $\mathrm{GM}_{\mathrm{o}}$ & : The initial metacentric height in $(\mathrm{m})$ \\
\hline $\mathrm{HM}$ & : Heeling Moment in (ton.m) \\
\hline IMO & : International Maritime Organization \\
\hline $\mathrm{K}$ & : Correction multiplier factor \\
\hline KG & $\begin{array}{l}\text { The vertical vessel's center of Gravity } \\
\text { (height above the keel) in (m) }\end{array}$ \\
\hline $\mathrm{R}$ & : Angle of Repose in (degree) \\
\hline MSC & : Maritime Safety Committee of IMO \\
\hline S.F. & : Stowage Factor $\left(\mathrm{m}^{3} / \mathrm{t}\right)$ \\
\hline SOLAS & : Safety Of Life At Sea \\
\hline SSC & Statical Stability Curve \\
\hline
\end{tabular}

\section{INTRODUCTION}

\subsection{Bulk Carrier's Definition}

The strict technical definition of a bulk carrier has been adopted by the SOLAS in 1999 [1], and it defines a

$\begin{array}{ll}\text { TSM } & : \begin{array}{c}\text { Volumetric Transverse Shifting } \\ \text { Moment }\left(\mathrm{m}^{4}\right)\end{array} \\ \Delta & : \text { Displacement in (ton) } \\ \rho & : \text { Density in }\left(\mathrm{t} / \mathrm{m}^{3}\right) \\ \theta & : \text { Heel angle in (degree) } \\ \phi_{\mathrm{f}} & : \text { Angle of flooding in (degree) } \\ \varphi_{\mathrm{h}} & : \text { Ship's angle of heel due to cargo } \\ & \text { shifting in (degree) } \\ \phi_{\mathrm{m}} & : \text { Angle of the maximum difference } \\ & \text { between righting arm and heeling } \\ & \text { arm in (degrees) } \\ \lambda_{\mathrm{o}} & : \text { Heeling arm at zero degrees in (m) } \\ \lambda_{40} & : \text { heeling arm at } 40 \text { degrees in }(\mathrm{m})\end{array}$

bulk carrier as a ship which has a single deck, top side tanks and hopper side tanks in cargo spaces, as shown in Figure1, and intended to primarily carry dry cargo in bulk (e.g. ore, cement, corn, grain, coal....etc.), [2].

\footnotetext{
${ }^{1}$ Egyptian Navigation Company, Alexandria, Egypt.E-mail:norhanghoneim@yahoo.com

${ }^{2}$ Faculty of Engineering ,Port Fouad, Port Said University, Egypt. E-mail: Hegazy@aast.com

${ }^{3}$ Faculty of Engineering, Alexandria University, Alexandria, Egypt. E-mail: Kotb2000@aast.com

${ }^{4}$ Faculty of Engineering, Port Fouad, Port Said University, Egypt. E-mail: Adil.tawfiq@gmail.com
} 


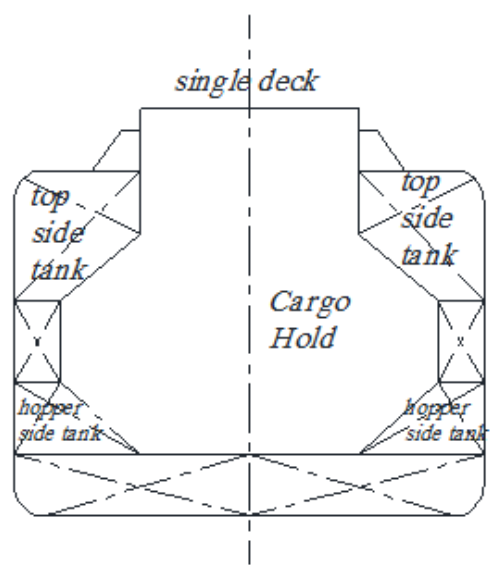

Figure 1: Typical cargo hold structural configuration for a single side skin bulk carrier

\section{$1.2 \quad$ Types of Bulk Carriers}

Bulk carriers can be divided on the basis of their loading/unloading facilities or their cargo carrying capacity as shown in Table 1 :

Table 1: Categories of bulk carrier

\begin{tabular}{|c|c|c|}
\hline \multirow{2}{*}{$\begin{array}{l}\text { On the basis of } \\
\text { the loading/ } \\
\text { unloading } \\
\text { facilities: }\end{array}$} & Geared Carriers & $\begin{array}{l}\text { This is a ship which has got its own gear (or equipment) to load or unload } \\
\text { cargo. This gear is in the form of cranes or derricks. }\end{array}$ \\
\hline & Gearless Carriers & $\begin{array}{l}\text { Some ships go away with the cranes and derricks but depend on the } \\
\text { equipment available at shore to load/discharge cargo and these are known } \\
\text { as gearless carriers. }\end{array}$ \\
\hline \multirow{5}{*}{$\begin{array}{l}\text { On the basis of } \\
\text { the cargo carrying } \\
\text { capacity: }\end{array}$} & $\begin{array}{l}\text { Mini bulk carriers } \\
\text { or MBCs }\end{array}$ & $\begin{array}{l}\text { Are relatively small bulk carriers usually have capacity less than } \\
10,000 \text { DWT. }\end{array}$ \\
\hline & $\begin{array}{l}\text { Handy size carriers } \\
\text { and Handy max } \\
\text { carriers }\end{array}$ & $\begin{array}{l}\text { Are general purpose ships in nature, [3]. These two segments represent } \\
71 \% \text { of all bulk carriers over } 10,000 \text { DWT and also have the highest rate } \\
\text { of growth [4]. Handymax ships are typically } 150-200 \mathrm{~m} \text { in length and } \\
52,000-58,000 \text { DWT. }\end{array}$ \\
\hline & $\begin{array}{l}\text { Panamax } \\
\text { carriers }\end{array}$ & $\begin{array}{l}\text { The size of a Panamax vessel is limited by the Panama canal's lock } \\
\text { chambers[5], which can accommodate ships with a beam of up to } \\
33.53 \mathrm{~m} \text {, a length overall up to } 320.04 \mathrm{~m} \text {, and a depth up to } 12.56 \mathrm{~m}[6] \text {. } \\
\text { The capacity of this type is } 60,000-99,999 \mathrm{dwt} \text {, [7]. }\end{array}$ \\
\hline & Capesize carrier & $\begin{array}{l}\text { Capesize ships are too large to traverse the Panama Canal and must round } \\
\text { Cape Horn to travel between the Pacific and Atlantic oceans, a standard } \\
\text { Capesize bulker is around } 175,000 \text { DWT, [8]. }\end{array}$ \\
\hline & $\begin{array}{l}\text { Very large bulk } \\
\text { carriers }\end{array}$ & $\begin{array}{l}\text { Very large bulk carriers are a subset of the capesize category reserved for } \\
\text { vessels over 200,000 DWT, [9]. }\end{array}$ \\
\hline
\end{tabular}

\section{BULK CARRIER'S STABILITY}

Solid bulk cargoes are usually loaded by pouring directly into a ship's cargo holds. If a solid bulk cargo is poured onto one spot, it naturally forms a conical pile with distinctive slope angle, called the Angle of Repose 'R'[10].
This is determined by the friction between the individual particles of the stow, which, in turn, depends upon the cargo commodity, its moisture content and the size and shape of the individual particles; see Figure2 and Table 2.

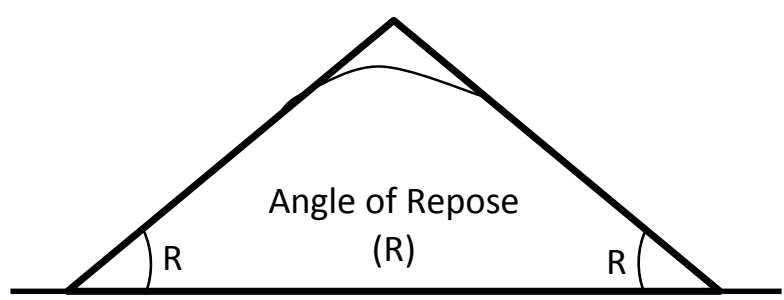

Figure 2: Angle of Repose for a solid bulk cargo [11] 
If a particularly heavy roll heels a vessel beyond the cargo's angle of repose, then the stow becomes unstable, as in condition 3, as shown in Figure 3. If the shift of cargo occurs, then the ship will roll about an angle of list so the return roll is unlikely to restore the cargo to the level state. Further rolling will produce even greater angles of heel towards the side of shifted cargo. This, in turn, can lead to further shifts of the stow which causes the list to progressively increase. The process will either capsize the ship or reach a stable listed state, depending upon the vessel's transverse stability characteristics.

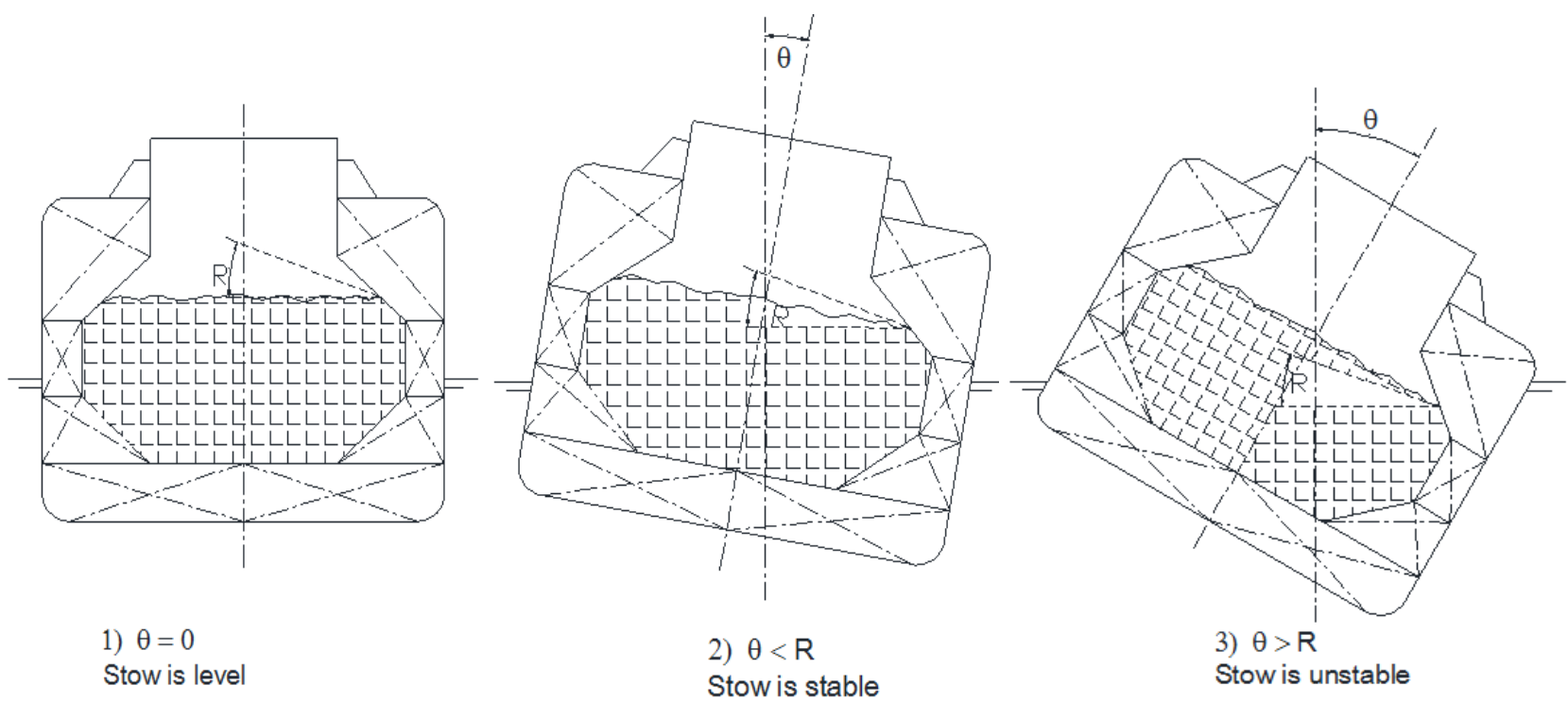

Figure 3: Behavior of a trimmed bulk cargo with angles of heel " $\theta$ "

Table 2: Examples of the angle of repose (R) and stowage factor (S.F.) of some different solid bulk cargoes in $\mathbf{m}^{3} / \mathbf{t}[12]$

\begin{tabular}{|l|c|c|}
\hline Solid Bulk Cargoes & S. F. $\left(\mathbf{m}^{\mathbf{3}} / \mathbf{t}\right)$ & Angle of Repose \\
\hline Ammonium Nitrate UN 1942 & 1 & $27^{\circ}$ to $42^{\circ}$ \\
\hline Ammonium Sulphate & 0.95 to 1.06 & $28^{\circ}$ to $35^{\circ}$ \\
\hline Monoammonium Phosphate & 1.0 to 1.21 & $35^{\circ}$ to $40^{\circ}$ \\
\hline Potash & 0.77 to 1.03 & $32^{\circ}$ to $35^{\circ}$ \\
\hline Potassium Chloride & 0.81 to 1.12 & $30^{\circ}$ to $47^{\circ}$ \\
\hline Superphosphate & 0.81 to 1.00 & $30^{\circ}$ to $40^{\circ}$ \\
\hline
\end{tabular}

\section{FORMULATION of BULK CARRIER STABILITY PROBLEM}

The angle of the heel due to solid bulk cargo shift $\left(\phi_{\mathrm{h}}\right)$ can be determined. Any bulk carrier, must have data, regarding the hold spaces, so that the $\mathrm{KG}$ and volumetric heeling moment for each stow can be calculated. TSM called simply the Moment of Water plane Inertia or, more correctly, the Second Moment of Area and this moment indicates the rate at which the underwater hull shape changes with angle of heel and it is an important factor in determining the hull form's resistance to rolling [13]. It is the moment caused by the shift in the Centre of Buoyancy per radian of water plane area rotation. This information is supplied by the shipbuilder in the form of tables or diagrams, for each cargo space, as shown in Figure4. Figure4 shows typical variations of volumetric heeling moment (curve No.1), stow's height of VCG from the keel (curve No.2) and volumetric capacity ( c u rve No.3) with hold ullage. The fluid KG of loaded vessel in the upright condition is calculated in the normal way by taking moments of individual weights about the keel and allowing for free surface effects of any slack tanks. Heights of cargo stows in the holds are obtained by measuring their ullages (i.e. the depths of the stow's top surface from the hatch top). The ullage values are used to obtain the $\mathrm{KG}$, volume and volumetric heeling moment of each grain stow. The weight of each stow is calculated as follows: 
Weight of cargo stow (ton) $=$ Volume of stow/Stowage factor

The value of the stowage factor, S.F. is generally used instead of bulk density, ' $\rho$ ' and should be supplied by the grain shipper, prior to loading.

$$
\text { S.F. }=1 / \rho\left(\mathrm{m}^{3} / \mathrm{t}\right)
$$

Values of KG and volumetric heeling moments must be corrected for all partially filled holds with the appropriate factors of ' $\mathrm{K}$ ', as shown below, before being used in the KG calculation.

The calculations' steps of the angle of heel due to solid bulk cargo shift $\left(\phi_{\mathrm{h}}\right)$ are as follows: a. Find out the Volumetric Transverse Shifting Moment (TSM) in $\left(\mathrm{m}^{4}\right)$ for each cargo hold corresponding to the loaded cargo's volume $\left(\mathrm{m}^{3}\right)$ from the vessel's tables.

b. In order to take into account the adverse effect of vertical shift of grain/bulk cargoes surfaces in "partially filled compartment", Volumetric Transverse Shifting Moment has to be multiplied by " $\mathrm{K}$ " where multiplier " $\mathrm{K}$ " is given by; according to [14];

- 1.06 For "fully filled compartments".

- 1.12 For "partly filled compartment".

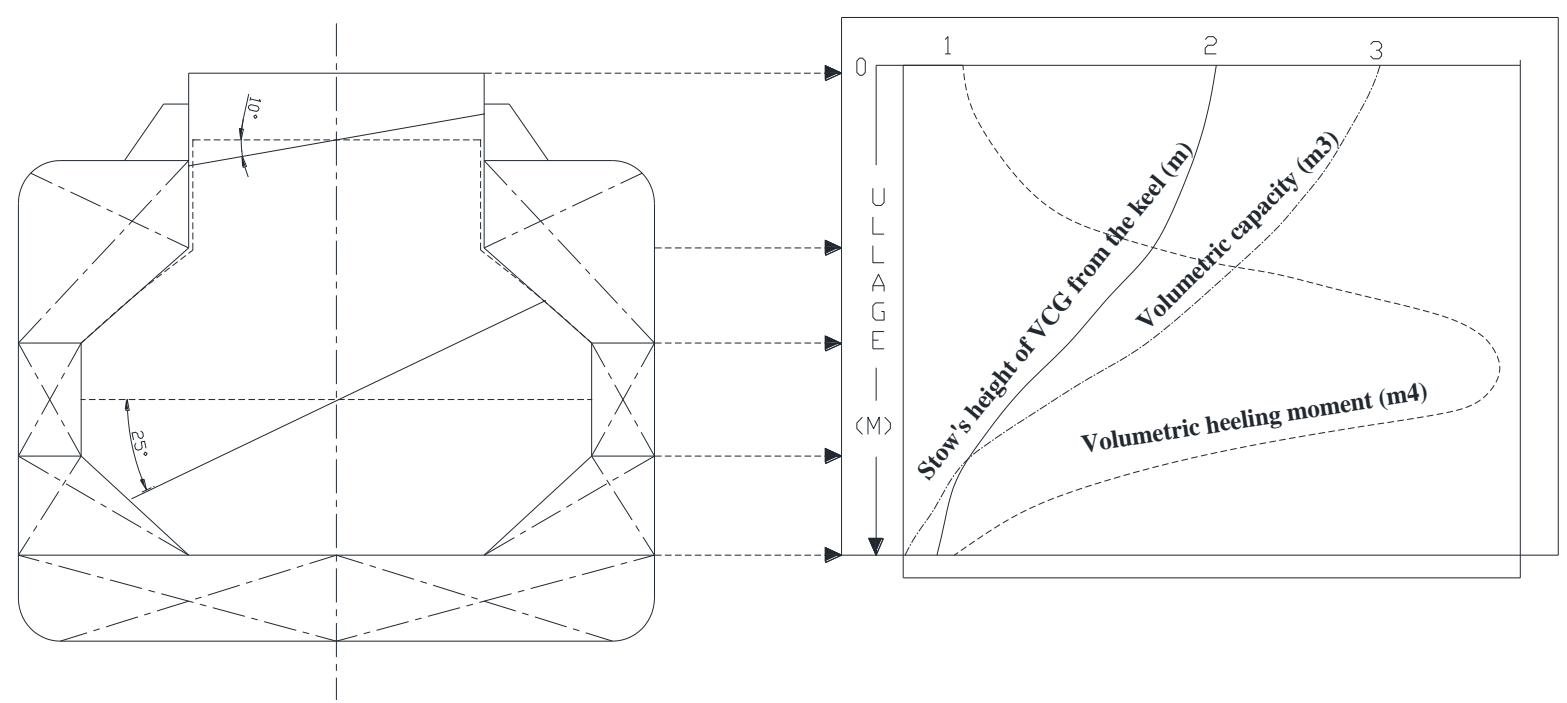

Figure 4: Grain Characteristics for a hold [11]

c. Transform Volumetric Transverse Heeling Moment (TSM) in $\left(\mathrm{m}^{4}\right)$ into Heeling Moment (HM) (t.m) from the following formula, [14]:

$$
\mathrm{HM}=\mathrm{K} . \mathrm{TSM}\left(\mathrm{m}^{4}\right) / \mathrm{S} . \mathrm{F} .\left(\mathrm{m}^{3} / \mathrm{t}\right) \quad \text { in }(\mathrm{t} . \mathrm{m})
$$

d. Find the value of heeling arm $\left(\lambda_{\mathrm{o}}\right)$ at zero and the value of heeling arm $\left(\lambda_{40}\right)$ at 40 degrees, respectively, by the formulae, [15]:

$$
\lambda_{0}=\frac{\text { Total Heeling Moment }(t . m)}{\text { Displacement }(\text { ton })}
$$

And

$$
\lambda_{40}=0.8 * \lambda_{0}
$$

Draw the heeling arm curve due to transverse grain shift which may be approximately represented by the straight line A-B where A and B are the ordinates. Find the intersection point between this curve and the righting arm curve. This point represents the angle of heel due to shift of grain $\left(\phi_{h}\right)$, see Figure 5 .

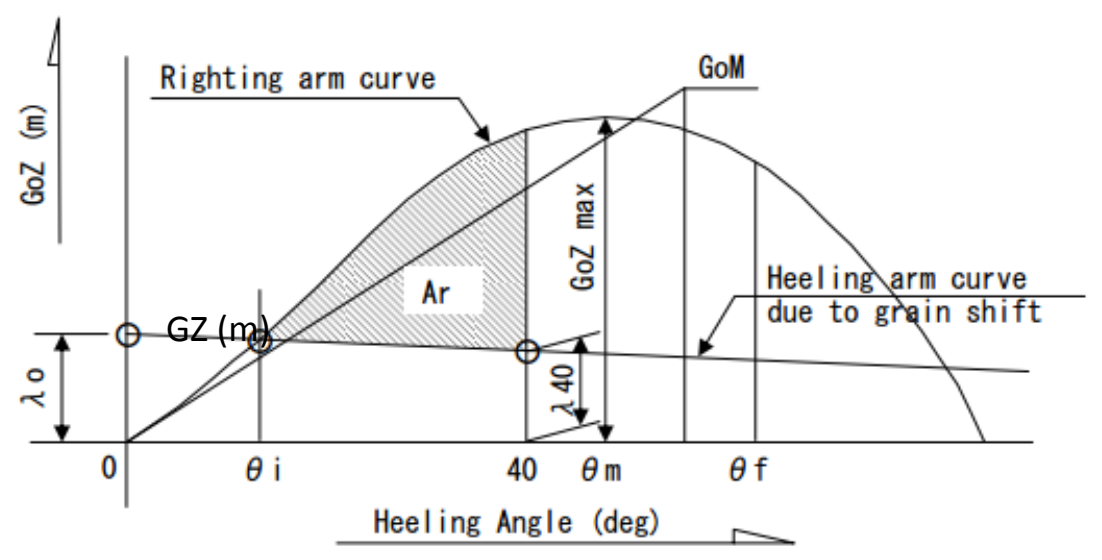

Figure 5: Determination of the angle of the heel due to solid bulk cargo shift $\left(\phi_{\mathrm{h}}\right)$ 


\section{THE STABILITY CRITERIA REQUIRED BY THE GRAIN REGULATIONS, [16]}

The intact stability criteria as per the Grain Regulations A.749 (18), [17], Maritime Safety Committee MSC.23(59), [18] and Chapter VI, SOLAS 1974, [19] according to the intact stability characteristics of any ship carrying bulk cargoes should meet, throughout the voyage, at least the following criteria after taking into account the heeling moments due to dry bulk cargo shift:

i. In the statical stability flow chart, see Figure 5, the net residual area between the heeling arm curve due to

\section{APPLICATION OF PROPOSED PROCEDURE}

In what follows an illustrative example given to show the procedure to be followed to investigate the

\subsection{Bulk Carrier's Specifications}

Table 3 summarizes the candidate vessel's principal particulars.

Table 3: Vessel Principal Particulars M/V "Gold Stone"

\begin{tabular}{ll}
\hline Length Over All (LOA) & $91.0 \mathrm{~m}$ \\
\hline Length between Perpendiculars (LBP) & $83.0 \mathrm{~m}$ \\
Breadth (B) & $15.0 \mathrm{~m}$ \\
Depth to main Deck (D) & $7.3 \mathrm{~m}$ \\
Summer Draft (T) & $6.0 \mathrm{~m}$ \\
Light Ship Weight & 1674.57 ton \\
Gross Tonnage & 2827 \\
Net Tonnage & 1822 \\
Engine Type & $6320 \mathrm{ZCD}-6$ \\
Engine Power & $1545 \mathrm{~K} . \mathrm{W}$ \\
Frame spacing & $600 \mathrm{~mm}$ \\
Longitudinal Center of gravity (LCG) & $-5.313 \mathrm{~m}$ (fore) \\
Vertical center of gravity (KG) & $5.70 \mathrm{~m}$ \\
Number of cargo holds & 2 \\
Year of Built & 2007 \\
\hline
\end{tabular}

\subsection{Stability Calculations Flow Chart}

A computer program is developed to carry out the stability calculations. The following flow chart, see Figure 6, explains the steps to meet the above mentioned criteria.

Table of offsets was developed and from these tables a model for the vessel was developed using Model Maker software. This model was used to carry out some loading conditions for the candidate vessel using AutoHydro software. Then the stability criteria for every loading condition were checked and analyzed as follows in the next sections of this paper.

\subsection{Loading Conditions}

Stability calculations are carried out at the following loading conditions:

a) Full load departure condition: transverse grain shift and the righting arm curve up to the angle of heel of maximum difference between the ordinates of the two curves, $\left(\phi_{\mathrm{m}}\right)$, or 40 degrees or the "angle of flooding", $\left(\phi_{\mathrm{f}}\right)$, whichever is the least, shall in all conditions not be less than 0.075 meter-radians; i.e, Residual Dynamical Stability $\geq 0.075$ (meterradians)

ii. The angle of heel due to shift of grain, $\phi_{\mathrm{h}}$, shall not be greater than 12 degrees i.e,

$$
\phi_{\mathrm{h}} \leq 12^{\circ}
$$

iii. The initial metacentric height, after correction for the free surface effects of liquids in tanks, shall not be less than 0.3 meters, i.e,

$$
\mathrm{GM}_{\mathrm{o}} \geq 0.3 \mathrm{~m}
$$

stability problem of bulk carriers at different conditions of loading with different types of bulk cargo.
The ship is fully loaded with cargo homogenously distributed through all cargo holds and with full stores and consumables, [20].

In this case:

Ship's displacement $(\Delta) \quad=6164.563$ Ton

Cargo weight $\quad=4184.283$ Ton

Draft $\quad=6 \mathrm{~m}$

No ballast water onboard

b) Half load (50\%) departure condition:

In this case:

Ship's displacement $(\Delta)=4072.4215$ Ton

Cargo weight $\quad=2092.1415$ Ton

Draft $\quad=6 \mathrm{~m}$

No ballast water onboard

c) $25 \%$ load departure condition:

In this case: 

Ship's displacement $(\Delta)=3026.351$ Ton
Draft
$=6 \mathrm{~m}$
Cargo weight$$
=1046.0708 \text { Ton }
$$
No ballast water onboard

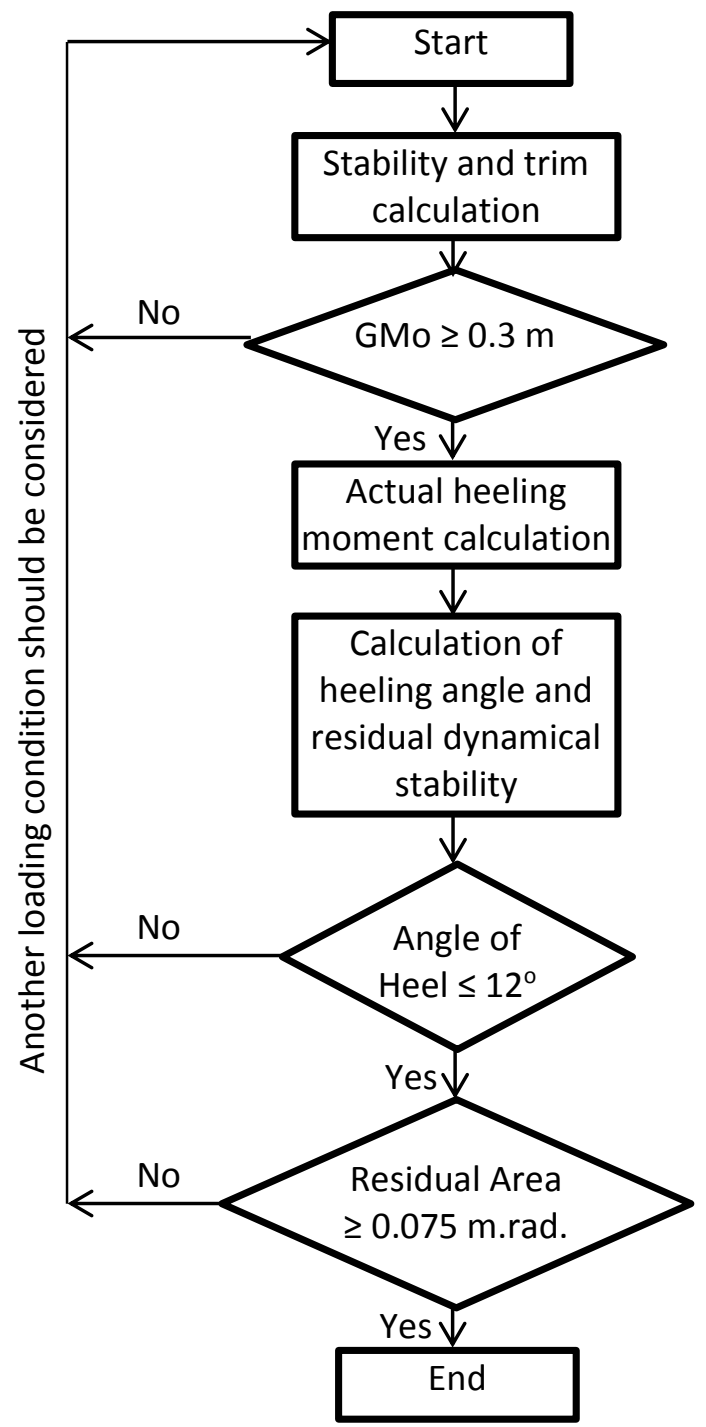

Figure 6: Stability diagram flow chart

\subsection{Different Types of Bulk Cargo}

The types of bulk cargo are represented by what so called stowage factor (S.F.) in $\left(\mathrm{m}^{3} /\right.$ ton $)$.

Bulk carriers usually designed to carry different types of bulk cargo with different stowage factors as given in Table 2.

This means that a bulk carrier must meet the stability grain regulations at all types of bulk cargo for which the ship is designed to carry. In this study the stability calculations for the vessel under consideration were carried out at different stowage factors, namely, $1.5,1.25,1.0,0.8$, and S.F. $0.667 \mathrm{~m}^{3} / \mathrm{t}$, to study the effect of the type of cargo on ship's stability for different loading condition (full load, half load,....etc.).

\section{RESULTS and DISCUSSION of THE PROCEDURE}

Figure 7 shows GZ - curve for full load departure with cargo onboard of $1.25 \mathrm{~m}^{3} / \mathrm{t}$ stowage factor while Table 4 gives the stability checkup for the same loading condition as an example of the obtained results for different loading conditions mentioned above.

Figure 8 shows GZ - curves for full load departure with different types of cargo (i.e. different values of S.F.). Also these results are given in Table 5.

It is clear from the figure that there are two areas, one of them is stable area where all stability criteria are satisfied (for S.F. $\geq 1.25 \mathrm{~m}^{3} / \mathrm{t}$ ), while the second area is unstable (for S.F. $\leq 1.0 \mathrm{~m}^{3} / \mathrm{t}$ ).

This means that the vessel under consideration is designed to carry light bulk cargo with S.F. $\geq 1.25 \mathrm{~m}^{3} / \mathrm{t}$.

In order that this vessel can carry safely heavy bulk cargo with $\mathrm{S} . \mathrm{F}$. $\leq 1 \mathrm{~m}^{3} / \mathrm{t}$, it must have onboard certain quantity of ballast water in certain ballast tanks 
located in the double bottom and this will reduce the

cargo earning capacity of the ship.

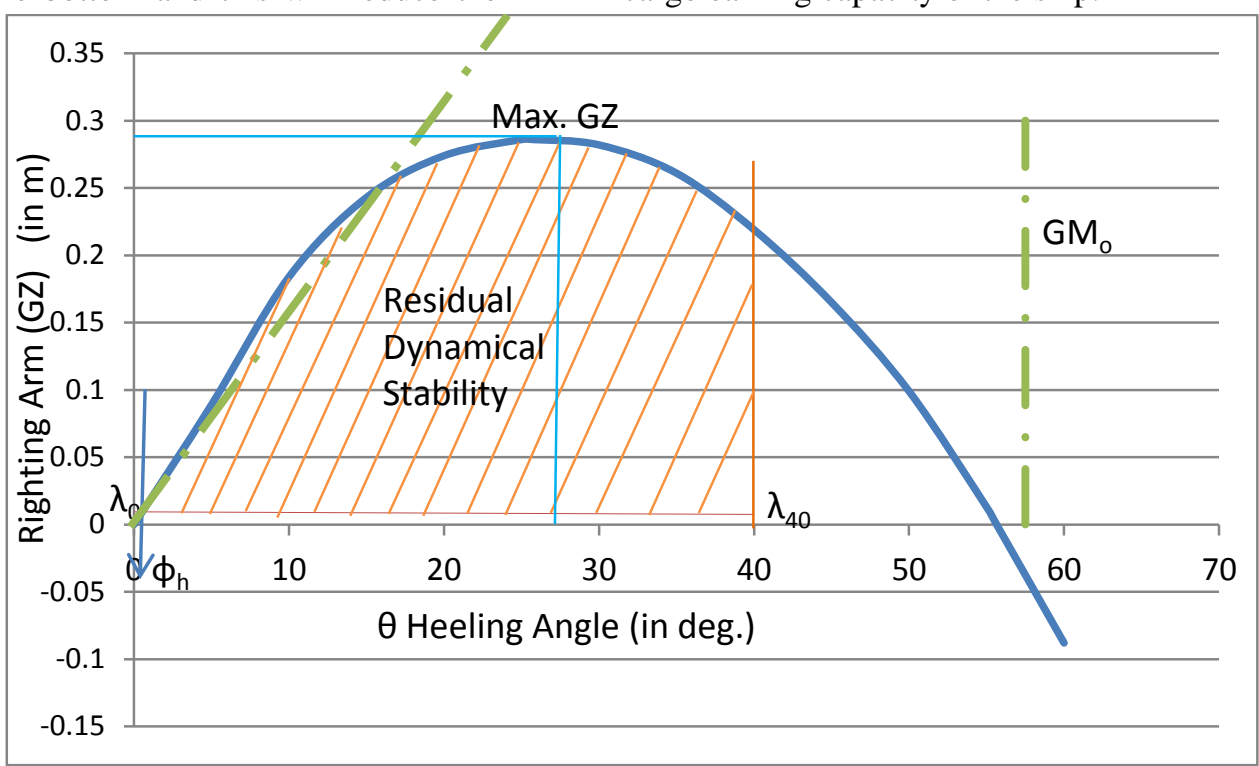

Figure 7: statically stability curve (SSC) for full load departure (S.F. $1.25 \mathrm{~m}^{3} /$ ton) as an output of the Autohydro software

Table 4: Stability checkup for full load departure (S.F. $1.25 \mathrm{~m}^{3} / \mathrm{ton}$ ) as an output of the Autohydro software

\begin{tabular}{|l|l|c|c|c|}
\hline & \multicolumn{1}{|c|}{ Min/Max } & Actual & Margin & Pass \\
\hline (1) Area from 0 deg. to 30 & $\geq 0.055 \mathrm{~m}-\mathrm{R}$ & 0.107 & 0.052 & Yes \\
\hline (2) Area from 0 deg. to 40or Flood & $\geq 0.09 \mathrm{~m}-\mathrm{R}$ & 0.152 & 0.062 & Yes \\
\hline (3) Area from 30 deg. to 40 or Flood & $\geq 0.03 \mathrm{~m}-\mathrm{R}$ & 0.045 & 0.015 & Yes \\
\hline (4) Righting Arm at 30 deg. & $\geq 0.2 \mathrm{~m}$ & 0.282 & 0.082 & Yes \\
\hline (5) Absolute Angle at Max. R.A. & $\geq 25 \mathrm{deg}$. & 27.31 & 2.31 & Yes \\
\hline (6) GM at Equilibrium & $\geq 0.15 \mathrm{~m}$ & 0.903 & 0.753 & Yes \\
\hline (7) Area from 0 deg. to 40 or Flood & $\geq 0.075 \mathrm{~m}-\mathrm{R}$ & 0.152 & 0.077 & Yes \\
\hline (8) GM at Equilibrium & $\geq 0.3 \mathrm{~m}$ & 0.903 & 0.603 & Yes \\
\hline
\end{tabular}

This was done and the results are shown on Figure 9. It was found that in the case of S.F. equals to $0.8 \mathrm{~m}^{3} / \mathrm{t}$, we have to carry an amount of 535.2 tons of water as a ballast to satisfy all stability criteria (see Table 5 and Table 6). As a result of ballasting operation the quantity of cargo to be carried onboard is reduced from 4184.283 tons to 3649.083 tons i.e. cargo earning capacity is reduced by $12.79 \%$.

For other loading conditions (i.e. $50 \%$ and $25 \%$ ) the results are shown on figure 10 (and table 7) and figure 11 (and table 8), respectively. It is clear that for these load conditions the vessel meet all grain stability criteria when loaded with different cargoes without need to carry ballast onboard.

It should be noted that one can say that for the same vessel and for the same loading condition, when the S.F. value increases (i.e. light cargo) the value of $\mathrm{KG}$ increases. In fact, in our case study, this is not usually true for all cases, since the cargo distribution in cargo holds as well as water ballast is not the same in all cases of loading conditions.

\section{CONCLUSIONS}

Bulk carriers comprise about one third of the world fleet in tonnage terms. Due to the nature of the bulk cargoes, bulk carriers face some stability problems.

For safe operation of such vessels IMO developed special stability criteria, which must be satisfied.

This paper gives a brief discussion of such regulations and a computer program was developed to carry out stability calculations for such vessels.

The effects of loading conditions as well as the type of bulk cargo carried onboard were examined. It was found that in some cases of loading conditions with 
certain type of cargo we have to use ballast water to satisfy the new grain regulations. This will lead to a reduction in the cargo earning capacity of the ship. The study under consideration is very important from the economic point of view of the vessel's operation. Ship's owners and charters must know which types of bulk cargoes are more profitable in case they have a choice to carry different types of bulk cargoes.

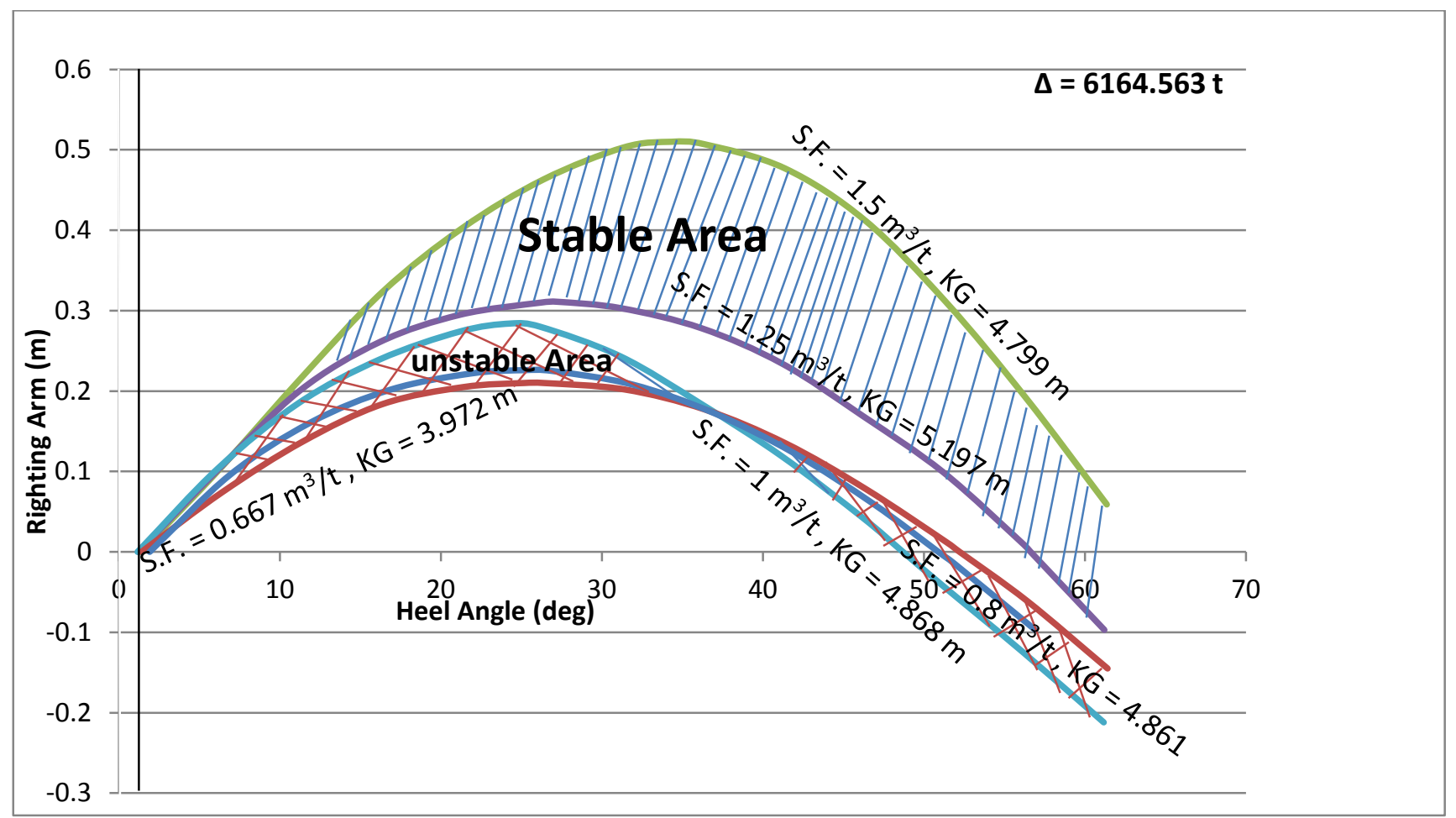

Figure 8: Righting Arm Curves (GZ Curve) in the Full Load Condition

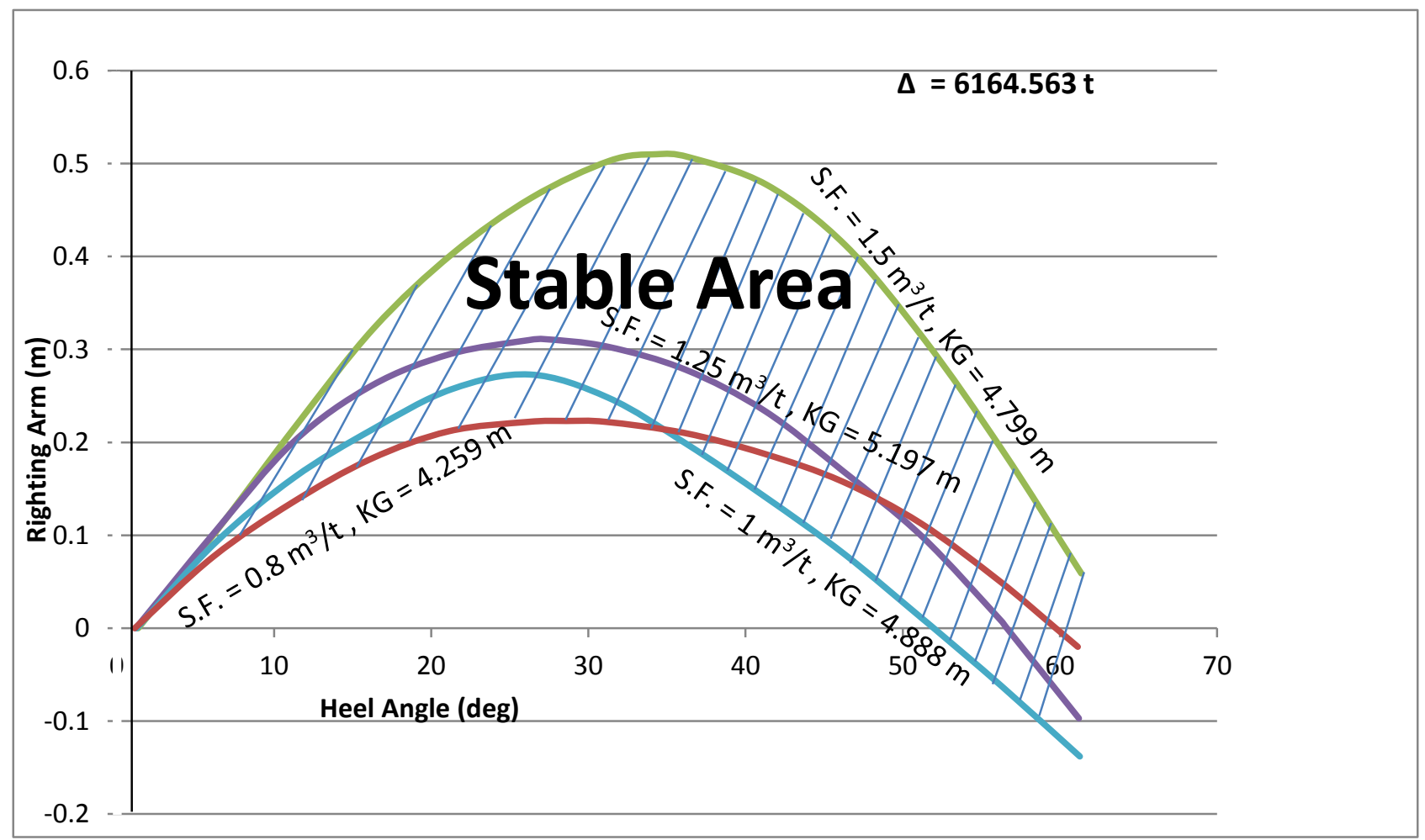

Figure 9: Righting Arm Curves (GZ Curve) in the Full Load Condition 


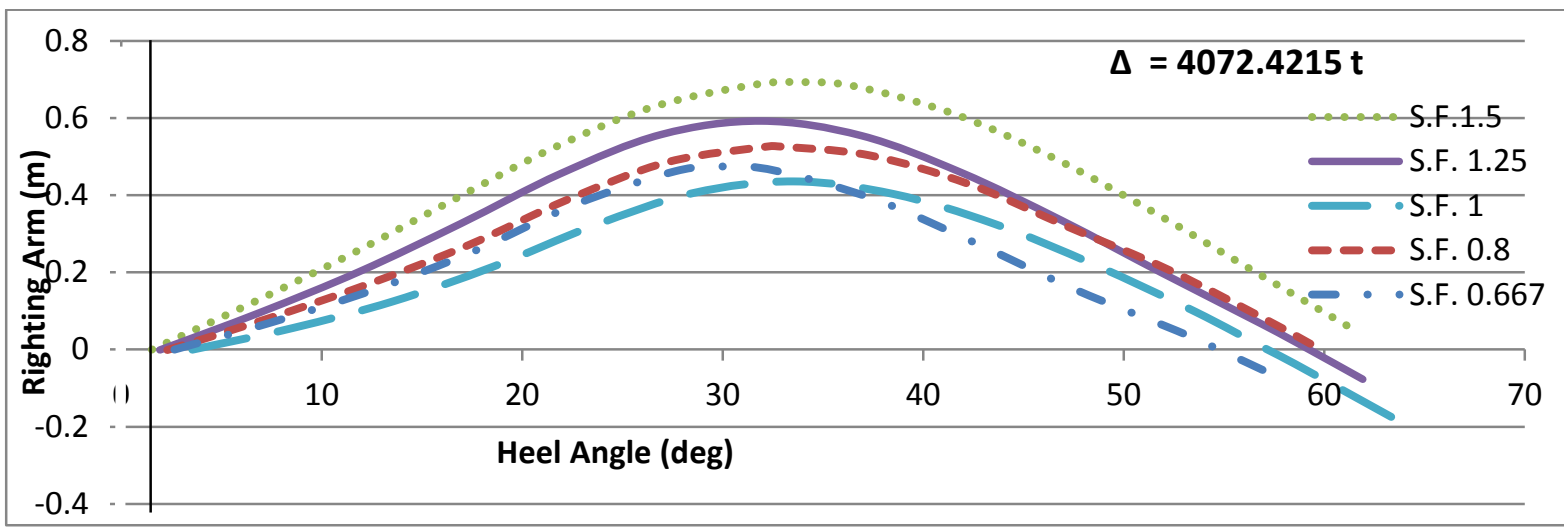

Figure 10: Righting Arm Curves (GZ Curve) in the Half Load (50\%) Departure Condition

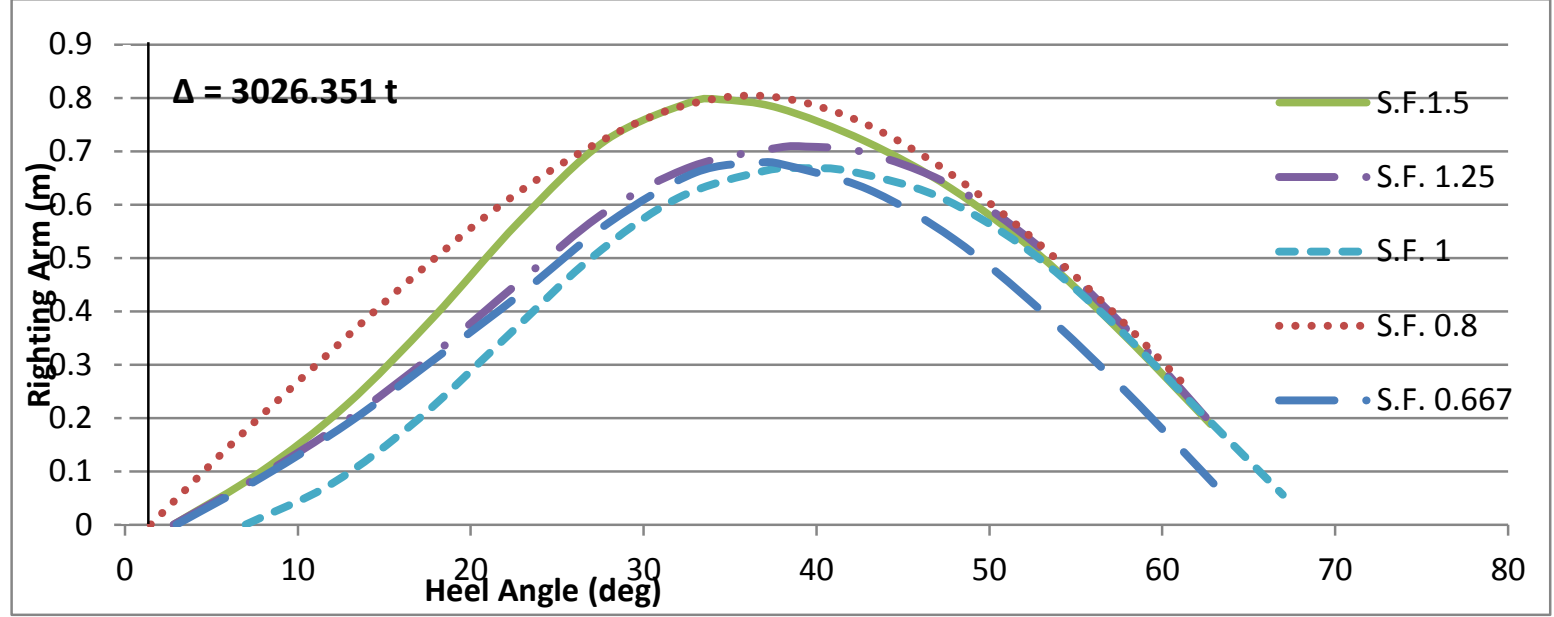

Figure 11: Righting Arm Curve (GZ Curve) in 25\% Loading Departure Conditions 
Table 5: Stability criteria for candidate ship in full load departure when loaded with bulk cargoes with different S.F.

\begin{tabular}{|c|c|c|c|c|c|c|c|c|c|c|}
\hline $\begin{array}{ll}\text { Item } & \text { Loading condition } \\
\end{array}$ & \multicolumn{10}{|c|}{ Full load departure (condition No.1) } \\
\hline$=$ & \multicolumn{2}{|c|}{ S.F. $=0.667$} & \multicolumn{2}{|c|}{ S.F. $=0.8$} & \multicolumn{2}{|c|}{ S.F. $=1$} & \multicolumn{2}{|c|}{ S.F. $=1.25$} & \multicolumn{2}{|c|}{ S.F. $=1.5$} \\
\hline Summer draft (m) & \multicolumn{10}{|c|}{6} \\
\hline Light ship weight (ton) & \multicolumn{10}{|c|}{$1,674.57$} \\
\hline Fixed weight (ton) & \multicolumn{10}{|c|}{3.5} \\
\hline Cargo in Hold (1) (ton) & \multicolumn{2}{|c|}{1683.4} & \multicolumn{2}{|c|}{697.056} & \multicolumn{2}{|c|}{$1,301.26$} & \multicolumn{2}{|c|}{1840.212} & \multicolumn{2}{|c|}{1531.905} \\
\hline Cargo in Hold (2) (ton) & \multicolumn{2}{|c|}{2500.883} & \multicolumn{2}{|c|}{3487.227} & \multicolumn{2}{|c|}{$2,880.56$} & \multicolumn{2}{|c|}{2281.455} & \multicolumn{2}{|c|}{1899.084} \\
\hline Consumables (ton) & \multicolumn{10}{|c|}{302.21} \\
\hline Deadweight (ton) & \multicolumn{10}{|c|}{4489.99} \\
\hline Ballast onboard (ton) & \multicolumn{2}{|c|}{70} & \multicolumn{2}{|c|}{ No ballast } & \multicolumn{2}{|c|}{ No ballast } & \multicolumn{2}{|c|}{62.616} & \multicolumn{2}{|c|}{753.2} \\
\hline Displacement (ton) & \multicolumn{10}{|c|}{6164.563} \\
\hline $\operatorname{VCG}(\mathrm{KG})(\mathrm{m})$ & \multicolumn{2}{|c|}{4.861} & \multicolumn{2}{|c|}{3.972} & \multicolumn{2}{|c|}{4.868} & \multicolumn{2}{|c|}{5.197} & \multicolumn{2}{|c|}{4.799} \\
\hline Stability criteria & Actual & Pass & Actual & Pass & Actual & Pass & Actual & Pass & Actual & Pass \\
\hline (1) Area from 0 deg. to $30 \geq 0.055 \mathrm{~m}-\mathrm{R}$ & 0.041 & No & 0.050 & $\underline{\mathrm{No}}$ & 0.104 & Yes & 0.107 & Yes & 0.145 & Yes \\
\hline (2) Area from 0 deg. to 40 or Flood $\geq 0.09 \mathrm{~m}-\mathrm{R}$ & 0.013 & $\underline{\underline{N o}}$ & 0.063 & $\underline{\mathrm{No}}$ & 0.135 & Yes & 0.152 & Yes & 0.220 & Yes \\
\hline (3) Area from $30 \mathrm{deg}$. to 40 or Flood $\geq 0.03 \mathrm{~m}-\mathrm{R}$ & -0.028 & $\underline{\underline{N o}}$ & 0.014 & $\underline{\mathrm{No}}$ & 0.030 & $\underline{\mathrm{No}}$ & 0.045 & Yes & 0.075 & Yes \\
\hline (4) Righting Arm at 30 deg. $\geq 0.2 \mathrm{~m}$ & -0.035 & No & 0.107 & $\underline{\mathrm{No}}$ & 0.242 & Yes & 0.282 & Yes & 0.417 & Yes \\
\hline (5) Absolute Angle at MaxRA $\geq 25 \mathrm{deg}$ & 16.92 & No & 22.62 & $\underline{\mathrm{No}}$ & 23.82 & $\underline{\text { No }}$ & 27.31 & Yes & 40.21 & Yes \\
\hline (6) $\mathrm{GM}$ at Equilibrium $\geq 0.15 \mathrm{~m}$ & 0.725 & Yes & 0.579 & Yes & 1.217 & Yes & 0.903 & Yes & 1.076 & Yes \\
\hline (7) Area from 0 deg to 40 or Flood $\geq 0.075 \mathrm{~m}-\mathrm{R}$ & 0.013 & $\underline{\text { No }}$ & 0.063 & $\underline{\mathrm{No}}$ & 0.135 & Yes & 0.152 & Yes & 0.220 & Yes \\
\hline (8) $\mathrm{GM}$ at Equilibrium $\geq 0.3 \mathrm{~m}$ & 0.725 & Yes & 0.579 & Yes & 1.217 & Yes & 0.903 & Yes & 1.076 & Yes \\
\hline (9) The angle of heel due to cargo shift, $\phi_{\mathrm{h}} \leq 12^{\circ}$ & 7.7 & Yes & 4.6 & Yes & 3.6 & Yes & 2.1 & Yes & 2 & Yes \\
\hline
\end{tabular}


Table 6: Stability criteria for candidate ship in full load departure when loaded with bulk cargoes with different S.F.

\begin{tabular}{|c|c|c|c|c|c|c|c|c|}
\hline $\begin{array}{ll}\text { Item } & \text { Loading condition } \\
\end{array}$ & \multicolumn{8}{|c|}{ Full load departure (condition No.1 with ballast water added) } \\
\hline Stowage factor & \multicolumn{2}{|c|}{ S.F. $=0.8$} & & & \multicolumn{2}{|c|}{ S.F. $=1.25$} & \multicolumn{2}{|c|}{ S.F. $=1.5$} \\
\hline Summer draft (m) & \multicolumn{8}{|c|}{6} \\
\hline Light ship weight (ton) & \multicolumn{8}{|c|}{$1,674.57$} \\
\hline Fixed weight (ton) & \multicolumn{8}{|c|}{3.5} \\
\hline Cargo in Hold (1) (ton) & \multicolumn{2}{|c|}{697.056} & \multicolumn{2}{|c|}{1335.658} & \multicolumn{2}{|c|}{1840.212} & \multicolumn{2}{|c|}{1531.905} \\
\hline Cargo in Hold (2) (ton) & \multicolumn{2}{|c|}{2952.027} & \multicolumn{2}{|c|}{2565.23} & \multicolumn{2}{|c|}{2281.455} & \multicolumn{2}{|c|}{1899.084} \\
\hline Consumables (ton) & \multicolumn{8}{|c|}{302.21} \\
\hline Deadweight (ton) & \multicolumn{8}{|c|}{4489.99} \\
\hline Ballast onboard (ton) & \multicolumn{2}{|c|}{535.2} & & & \multicolumn{2}{|c|}{62.616} & \multicolumn{2}{|c|}{753.2} \\
\hline Displacement (ton) & \multicolumn{8}{|c|}{6164.563} \\
\hline VCG $(\mathrm{KG})(\mathrm{m})$ & \multicolumn{2}{|c|}{4.259} & \multicolumn{2}{|c|}{4.888} & \multicolumn{2}{|c|}{5.197} & \multicolumn{2}{|c|}{4.799} \\
\hline Stability criteria & Actual & Pass & Actual & Pass & Actual & Pass & Actual & Pass \\
\hline (1) Area from 0 deg. to $30 \geq 0.055 \mathrm{~m}-\mathrm{R}$ & 0.083 & Yes & 0.099 & Yes & 0.107 & Yes & 0.145 & Yes \\
\hline (2) Area from 0 deg. to 40 or Flood $\geq 0.09 \mathrm{~m}-\mathrm{R}$ & 0.119 & Yes & 0.133 & Yes & 0.152 & Yes & 0.220 & Yes \\
\hline (3) Area from 30 deg. to 40 or Flood $\geq 0.03 \mathrm{~m}-\mathrm{R}$ & 0.036 & Yes & 0.034 & Yes & 0.045 & Yes & 0.075 & Yes \\
\hline (4) Righting Arm at 30 deg. $\geq 0.2 \mathrm{~m}$ & 0.222 & Yes & 0.248 & Yes & 0.282 & Yes & 0.417 & Yes \\
\hline (5) Absolute Angle at MaxRA $\geq 25 \mathrm{deg}$ & 28.61 & Yes & 26.27 & Yes & 27.31 & Yes & 40.21 & Yes \\
\hline (6) $\mathrm{GM}$ at Equilibrium $\geq 0.15 \mathrm{~m}$ & 1.030 & Yes & 1.060 & Yes & 0.903 & Yes & 1.076 & Yes \\
\hline (7) Area from 0 deg to 40 or Flood $\geq 0.075 \mathrm{~m}-\mathrm{R}$ & 0.119 & Yes & 0.133 & Yes & 0.152 & Yes & 0.220 & Yes \\
\hline (8) $\mathrm{GM}$ at Equilibrium $\geq 0.3 \mathrm{~m}$ & 1.030 & Yes & 1.060 & Yes & 0.903 & Yes & 1.076 & Yes \\
\hline (9) The angle of heel due to cargo shift, $\phi_{\mathrm{h}} \leq 12^{\circ}$ & 3.1 & Yes & 2.8 & Yes & 2.1 & Yes & 2 & Yes \\
\hline
\end{tabular}


Table 7: Stability criteria for candidate ship in half load departure when loaded with bulk cargoes with different S.F.

\begin{tabular}{|c|c|c|c|c|c|c|c|c|c|c|}
\hline \multirow{2}{*}{$\begin{array}{ll}\text { Item } & \text { Loading condition } \\
& \text { Stowage factor } \\
\end{array}$} & \multicolumn{10}{|c|}{ Half load departure (condition No.3) } \\
\hline & \multicolumn{2}{|c|}{ S.F. $=0.667$} & \multicolumn{2}{|c|}{ S.F. $=0.8$} & \multicolumn{2}{|c|}{ S.F. $=1$} & \multicolumn{2}{|c|}{ S.F. $=1.25$} & \multicolumn{2}{|c|}{ S.F. $=1.5$} \\
\hline Summer draft (m) & \multicolumn{10}{|c|}{6} \\
\hline Light ship weight (ton) & \multicolumn{10}{|c|}{$1,674.57$} \\
\hline Fixed weight (ton) & \multicolumn{10}{|c|}{3.5} \\
\hline Cargo in Hold (1) (ton) & \multicolumn{2}{|c|}{2092.142} & \multicolumn{2}{|c|}{2092.142} & \multicolumn{2}{|c|}{1161.505} & \multicolumn{2}{|c|}{929.4} & \multicolumn{2}{|c|}{774.55} \\
\hline Cargo in Hold (2) (ton) & \multicolumn{2}{|c|}{0} & \multicolumn{2}{|c|}{0} & \multicolumn{2}{|c|}{930.6365} & \multicolumn{2}{|c|}{1162.742} & \multicolumn{2}{|c|}{1317.592} \\
\hline Consumables (ton) & \multicolumn{10}{|c|}{302.21} \\
\hline Deadweight (ton) & \multicolumn{10}{|c|}{2397.85} \\
\hline Ballast onboard (ton) & \multicolumn{2}{|c|}{ No ballast } & \multicolumn{2}{|c|}{ No ballast } & \multicolumn{2}{|c|}{ No ballast } & \multicolumn{2}{|c|}{ No ballast } & \multicolumn{2}{|c|}{ No ballast } \\
\hline Displacement (ton) & \multicolumn{10}{|c|}{4072.4215} \\
\hline Stability criteria & Actual & Pass & Actual & Pass & Actual & Pass & Actual & Pass & Actual & Pass \\
\hline (1) Area from 0 deg. to $30 \geq 0.055 \mathrm{~m}-\mathrm{R}$ & 0.136 & Yes & 0.145 & Yes & 0.117 & Yes & 0.169 & Yes & 0.197 & Yes \\
\hline (2) Area from 0 deg. to 40 or Flood $\geq 0.09 \mathrm{~m}-\mathrm{R}$ & 0.203 & Yes & 0.231 & Yes & 0.186 & Yes & 0.264 & Yes & 0.314 & Yes \\
\hline (3) Area from 30 deg. to 40 or Flood $\geq 0.03 \mathrm{~m}-\mathrm{R}$ & 0.067 & Yes & 0.086 & Yes & 0.069 & Yes & 0.095 & Yes & 0.117 & Yes \\
\hline (4) Righting Arm at 30 deg. $\geq 0.2 \mathrm{~m}$ & 0.463 & Yes & 0.526 & Yes & 0.436 & Yes & 0.592 & Yes & 0.686 & Yes \\
\hline (5) Absolute Angle at MaxRA $\geq 25 \mathrm{deg}$ & 30.20 & Yes & 32.74 & Yes & 33.55 & Yes & 31.93 & Yes & 33.83 & Yes \\
\hline (6) $\mathrm{GM}$ at Equilibrium $>0.15 \mathrm{~m}$ & 0.813 & Yes & 0.908 & Yes & 0.610 & Yes & 1.078 & Yes & 1.362 & Yes \\
\hline (7) Area from 0 deg to 40 or Flood $\geq 0.075 \mathrm{~m}-\mathrm{R}$ & 0.203 & Yes & 0.231 & Yes & 0.186 & Yes & 0.264 & Yes & 0.314 & Yes \\
\hline (8) $\mathrm{GM}$ at Equilibrium $\geq 0.3 \mathrm{~m}$ & 0.813 & Yes & 0.908 & Yes & 0.610 & Yes & 1.078 & Yes & 1.362 & Yes \\
\hline
\end{tabular}


Table 8: Stability criteria for candidate ship in $25 \%$ load arrival when loaded with bulk cargoes with different S.F.

\begin{tabular}{|c|c|c|c|c|c|c|c|c|c|c|}
\hline $\begin{array}{ll}\text { Item } & \text { Loading condition } \\
\end{array}$ & \multicolumn{10}{|c|}{$25 \%$ load arrival (condition No.5) } \\
\hline Stowage factor & \multicolumn{2}{|c|}{ S.F. $=0.667$} & \multicolumn{2}{|c|}{ S.F. $=0.8$} & \multicolumn{2}{|c|}{ S.F. $=1$} & \multicolumn{2}{|c|}{ S.F. $=1.25$} & \multicolumn{2}{|c|}{ S.F. $=1.5$} \\
\hline Summer draft (m) & \multicolumn{10}{|c|}{6} \\
\hline Light ship weight (ton) & \multicolumn{10}{|c|}{$1,674.57$} \\
\hline Fixed weight (ton) & \multicolumn{10}{|c|}{3.5} \\
\hline Cargo in Hold (1) (ton) & \multicolumn{2}{|c|}{1046.071} & \multicolumn{2}{|c|}{1046.071} & \multicolumn{2}{|c|}{696.903} & \multicolumn{2}{|c|}{557.64} & \multicolumn{2}{|c|}{774.55} \\
\hline Cargo in Hold (2) (ton) & \multicolumn{2}{|c|}{0} & \multicolumn{2}{|c|}{0} & \multicolumn{2}{|c|}{349.1678} & \multicolumn{2}{|c|}{488.4308} & \multicolumn{2}{|c|}{271.5208} \\
\hline Consumables (ton) & \multicolumn{10}{|c|}{302.21} \\
\hline Deadweight (ton) & \multicolumn{10}{|c|}{1351.78} \\
\hline Ballast onboard (ton) & \multicolumn{2}{|c|}{ No ballast } & \multicolumn{2}{|c|}{ No ballast } & \multicolumn{2}{|c|}{ No ballast } & \multicolumn{2}{|c|}{ No ballast } & \multicolumn{2}{|c|}{ No ballast } \\
\hline Displacement (ton) & \multicolumn{10}{|c|}{3026.3508} \\
\hline Stability criteria & Actual & Pass & Actual & Pass & Actual & Pass & Actual & Pass & Actual & Pass \\
\hline (1) Area from 0 deg. to $30 \geq 0.055 \mathrm{~m}-\mathrm{R}$ & 0.168 & Yes & 0.197 & Yes & 0.181 & Yes & 0.173 & Yes & 0.209 & Yes \\
\hline (2) Area from 0 deg. to 40 or Flood $\geq 0.09 \mathrm{~m}-\mathrm{R}$ & 0.284 & Yes & 0.322 & Yes & 0.295 & Yes & 0.295 & Yes & 0.344 & Yes \\
\hline (3) Area from $30 \mathrm{deg}$. to 40 or Flood $\geq 0.03 \mathrm{~m}-\mathrm{R}$ & 0.116 & Yes & 0.126 & Yes & 0.114 & Yes & 0.122 & Yes & 0.135 & Yes \\
\hline (4) Righting Arm at 30 deg. $\geq 0.2 \mathrm{~m}$ & 0.660 & Yes & 0.726 & Yes & 0.663 & Yes & 0.672 & Yes & 0.793 & Yes \\
\hline (5) Absolute Angle at MaxRA $\geq 25 \mathrm{deg}$ & 36.72 & Yes & 35.19 & Yes & 39.37 & Yes & 39.37 & Yes & 34.40 & Yes \\
\hline (6) $\mathrm{GM}$ at Equilibrium $>0.15 \mathrm{~m}$ & 0.994 & Yes & 1.208 & Yes & 0.696 & Yes & 1.037 & Yes & 1.065 & Yes \\
\hline (7) Area from 0 deg to 40 or Flood $\geq 0.075 \mathrm{~m}-\mathrm{R}$ & 0.284 & Yes & 0.322 & Yes & 0.295 & Yes & 0.295 & Yes & 0.344 & Yes \\
\hline (8) $\mathrm{GM}$ at Equilibrium $\geq 0.3 \mathrm{~m}$ & 0.994 & Yes & 1.208 & Yes & 0.696 & Yes & 1.037 & Yes & 1.065 & Yes \\
\hline
\end{tabular}




\section{REFERENCES:}

[1]http://www.brighthub.com/engineering/marine/articl es/11736.aspx, last updated 7/12/2009.

[2] SOLAS - International Convention for the Safety of Life at Sea - Articles of the International Convention for the Safety of Life at Sea, 1974.

[3] http://en.wikipedia.org/wiki/Handysize, last updated January 2010.

[4] http://en.wikipedia.org/wiki/Handymax, last updated 12/11/2010.

[5] Autoridad Del Canal de Panamá 2005, pp.11 - 12, http://en.wikipedia.org/wiki/Panamax, 25 July 2013.

[6] http://maritimeconnector.com/wiki/panamax.

[7] United Nations Conference on trade and development UNCTAD, Review of Maritime Transport 2014, UNCTAD/RMT/2014 UNITED NATIONS publication, 2014.

[8] Reuters Africa, Thomson Reuters (af.reuters.com), 26 July 2010. http://en.wikipedia.org/wiki/Capesize, "Egypt's Suez Canal H1 revenue, traffic up; upgrade helps". Retrieved 26 March 2011.

[9] MAN Diesel Group, p.3-4, http://maritimeconnector.com/wiki/vlcc/, 2005.

[10] Edward V. Lewis, Principles of Naval Architecture VOL I, stability and strength, Editor, Published by the society of naval architects and marine engineers, 601 Pavonia Avenue, Jersey City, NJ, 1988.

[11] BC 2004 Code - Code of Safe Practice for Solid Bulk Cargoes, 2004 Resolution MSC.193(79) - Section 1 - Definitions, 2004.
[12] Resolution MSC.268 (85) - Adoption of the International Maritime Solid Bulk Cargoes (IMSBC) Code - The Maritime Safety Committee, Adopted 4 December 2008.

[13] K.J. Rawson and E.C. Tupper, Basic Ship Theory, $5^{\text {th }}$ ed.,volume 2, Published by the Longman Group Ltd., 2001.

[14] David G.M. Watson, Practical ship design, Published by the Elsevier Science Ltd., The Boulevard, Oxford, UK 1998.

[15] Ian. C. Clark, The Management of merchant Ship Stability, Trim and Strength, first published 2002 by The Nautical Institute, London, England, 2002.

[16] The International Maritime Organization (I.M.O.) 'Code of Intact Stability', 1995.

[17] IMO Resolution A.749(18) - Code on Intact Stability for all Types of Ships Covered by IMO Instruments , adopted on 4 November 1993.

[18] Resolution MSC.23(59) - Adoption of the International Code for the Safe Carriage of Grain in Bulk, adopted on 23 May 1991.

[19] SOLAS - International Convention for the Safety of Life at Sea - Articles of the International Convention for the Safety of Life at Sea, Chapter VI - Carriage of cargoes and oil fuels, SOLAS 1974.

[20] Intact Stability (IS) Code - Intact Stability for All Types of Ships Covered by IMO Instruments, Resolution A.749(18), Amended by MSC.75(69), Adopted on 14 May 1998. 